\title{
Barriers to E-Commerce Adoption in Egyptian SMEs
}

\author{
Abdel Nasser H. Zaied \\ Vice-dean for Education and Students Affairs, \\ College of Computers and Informatics, \\ Zagazig University, Egypt \\ nasserhr@zu.edu.eg, nasserhr@gmail.com
}

\begin{abstract}
E-commerce has been predicted to be a new driver of economic growth for developing countries. The SME sector plays a significant role in its contribution to the national economy in terms of the wealth created and the number of people employed. Small and Medium Enterprises (SMEs) in Egypt represent the greatest share of the productive units of the Egyptian economy and the current national policy directions address ways and means of developing the capacities of SMEs. Many factors could be responsible for the low usage of e-commerce among the SMEs in Egypt. In order to determine the factors that promote the adoption of e-commerce, SMEs adopters and non-adopters of e-commerce were asked to indicate the factors inhibiting the adoption of ecommerce. The results show that technical barriers are the most important barriers followed by legal and regulatory barriers, whereas lack of Internet security is the highest barrier that inhibit the implementation of ecommerce in SMEs in Egypt followed by limited use of Internet banking and web portals by SMEs. Also, findings implied that more efforts are needed to help and encourage SMEs in Egypt to speed up e-commerce adoption, particularly the more advanced applications.
\end{abstract}

Index Terms - E-commerce adoption, e-commerce adoption barriers, Small and Medium Enterprises, ecommerce adoption in SMEs in Egypt

\section{INTRODUCTION}

The slow pace of e-commerce diffusion in SMEs sector has led to a variety of studies. These studies have reported that SMEs are generally lagging behind to large organizations as far as the adoption and usage of e-commerce is concerned ${ }^{[1]}$. Fillis et al. ${ }^{[2]}$ examined the adoption of e-commerce by SMEs and found that SMEs could gain competitive advantage through adopting e-commerce as it could improve their market performance by having better access to the market. Bolongkikit et al. ${ }^{[3]}$ found among other issues that SMEs markets needed a high degree of human interaction. Taylor \& Murphy ${ }^{[4]}$ argued that SMEs occupy small / clearly defined niche markets that do not need global connectivity through experimentation as inhibitors to e-commerce adoption. Organizations adopting e-commerce in developing countries face problems such as lack of telecommunications infrastructure, lack of qualified staff to develop and support e-commerce sites, lack of skills among consumers needed in order to use the Internet, lack of timely and reliable systems for the delivery of physical goods, low bank account and credit card penetration, low income, and low computer and Internet penetration ${ }^{[5]}$.

The main objectives of this study are to investigate the barriers to e-commerce adoption in Egyptian SMEs and to suggest some recommendations for applying ecommerce successfully. The work begins by examining the nature of SMEs and e-commerce followed by discussing the barriers to e-commerce adoption based on previous research. The remainder of this paper is structured as follows: In the next section, a presentation of research methodology employed in the work was described. The results were later presented and discussion of the findings followed. The conclusions and recommendations finalized the paper.

\section{SMALL AND MEDIUM ENTERPRISES (SMES)}

Most of the international economies depend basically on the role of SMEs in supporting the national economy in different countries. SMEs contribute significantly to the economies of the African continent, representing around $90 \%$ of all businesses, and providing the main source of jobs and income for African people. In the non-oil-exporting states of the region, such as Egypt, SMEs account for a greater proportion of economic activity and international development organizations are active ${ }^{[6]}$. In Egypt, SMEs historically played a relatively significant role in the process of economic development. The definition of SMEs is not unique; it varies across countries and in some countries, the definition differs further between sectors. Number of people employed and size of capital, sales, assets, etc. are used to classify enterprises into micro, small, and medium. The Egyptian Ministry of Industry (MOI) classified SMEs based on 'labor' and 'investment costs' criteria. Small and medium enterprises are defined as those having 10-49 and 50- 
99 workers respectively. As to the ceilings for investment costs, they are set at LE 5 million and LE 10 million for the two groups of enterprises respectively ${ }^{[7]}$.

\section{E-COMMERCE}

Electronic commerce refers to conducting business transactions over the Internet, which includes exchange of information of value in the form of products and services as well as payments, using web-based technologies ${ }^{[8]}$. Eurostat ${ }^{[9]}$ defined e-commerce as transactions conducted over Internet Protocol-based (IP) networks or over other computermediated net-works (e.g. EDI if not carried out via IP). The Internet and e-commerce are transforming the way firms operate by redefining how back-end operations are conducted ${ }^{[10]}$. Studies of e-commerce issues in developed countries indicate that issues faced by SMEs in developing countries can be totally different ${ }^{[11]}$. Many SMEs in developing countries are not achieving even minimal levels of e-commerce adoption, also the adoption of web-enabled transaction processing by small business has not been as widespread as would are expected ${ }^{[12]}$. It has been demonstrated previously that the rate of e-commerce adoption in SMEs has been low.

\section{BARRIERS TO E-COMMERCE ADOPTION IN SMES IN DEVELOPING COUNTRIES}

Although research indicates e-commerce offers viable and practical solutions for organizations to meet challenges of a predominantly changing environment, the available studies related to SMEs in developing countries reveal a delay or failure of SMEs in adopting e-commerce.

\subsection{Early e-commerce adoption barriers in SMEs}

Various sources of literature show that barriers to ecommerce adoption and diffusion in

SMEs were initially reported in the period 1990 to 1999. In 1999, El-Nawawy and Ismail ${ }^{[13]}$ in their study of e-commerce adoption by SMEs in Egypt reported that the main factors revolve around awareness and education, market size, e-commerce infrastructure, telecommunications infrastructure, legal system, government issues, affordability/cost structure and social and psychological factors. Also in a study of SME adoption of e-commerce in South Africa by Cloete et al. ${ }^{[14]}$, authors reported several factors which affect the adoption of e- commerce in MSEs which include lack of information options, lack of time to investigate options, lack of access to computers, lack of access to hardware and software, limited knowledge of e- commerce models and methodologies. In 2004, Chen ${ }^{[15]}$ studied the reasons behind the slow adoption of electronic commerce by the Small and Medium Enterprises (SMEs) in Taiwan. The results showed that financial shortage and concern over lack of IT employees rank as the top two barriers to adoption of e-commerce by SMEs in Taiwan.

\subsection{Recent e-commerce barriers in SMEs}

In the period 2005 and beyond, several studies were also abounding with new barriers on e-commerce adoption in SMEs. Kaynak et al. ${ }^{[16]}$ reported on the difficulty of finding and retaining qualified personnel with required skills and knowledge and the risk of dissipation of company specific knowledge. Whereas, Bolongkikit et al. ${ }^{[3]}$ found among other issues that SMEs markets needed a high degree of human interaction. In 2007, Kshetri ${ }^{[17]}$ analyzed e-commerce barriers in terms of three categories: economic barriers, sociopolitical barriers and cognitive barriers. Whereas, Rakhmanov ${ }^{[18]}$ presented the main barriers affecting egovernment development in Uzbekistan which negatively affected people's decisions to use the technology and inhibited decision makers from implementing or adopting e-government initiatives. Recently, Olatokun and Kebonye ${ }^{[19]}$, assessed the adoption of e-commerce by SMEs in Botswana and found out the factors that led to e-commerce adoption, the kinds of e-commerce technologies that were adopted and used, as well as the services provided with these technologies. Also, Alshehri and Drew ${ }^{[20]}$, studied the e-ready (readiness) of Saudi citizens to identify the challenges and barriers that affect the adoption of e-government services in Saudi society. They classified the barriers into five barriers: technical, organizational, social, management support and financial barriers. More recently, Alamro and Tarawneh ${ }^{[21]}$ summarized the factors influencing ecommerce adoption in SMEs in Jordan into three contexts; these contexts were external environmental context (strong competition, global economy, regional trade agreements, extremely low labor cost in some countries, frequent and significant changes in markets and increased power of consumer). organizational context (changing nature of workforce, management support, financial resources, increased importance of ethical and legal issues, increased social responsibility of organizations and rapid political changes) and technological context (increase innovations and new technologies, e-commerce benefits, e-commerce barriers and rapid decline in technology cost vs. performance ratio). Some of e-commerce adoption barriers in SMEs are summarized in Table (1). 
Table (1): Recent e-commerce adoption barriers in SMEs

\begin{tabular}{|c|c|}
\hline Barriers to e-commerce & Sources \\
\hline Absence of legal and regulatory systems & {$[22] \&[23]$} \\
\hline Change in regulations with each Government & [5] \& [22] \\
\hline Changes in government policy & [5] \& [23] \\
\hline Competitive pressure & {$[10] \&[22]$} \\
\hline Computer illiteracy & [24] \& [25] \\
\hline Cost too high & {$[20] ;[23] ;[26] ;[27] \&[28]$} \\
\hline Culture differences & {$[20]$} \\
\hline Difficulty in changing the existing working procedures & [20]; [28] \& [29] \\
\hline E-commerce infrastructure & {$[5] ;[17] \&[30]$} \\
\hline Inadequate quality and speed of lines & {$[22] ;[23] ;[24] \&[28]$} \\
\hline Increase innovations and new technologies & {$[20] \&[21]$} \\
\hline Lack of an appropriate legal environment to apply e-commerce & {$[23] ;[24] ;[25] \&[30]$} \\
\hline Lack of e-trading legislations & {$[22] ;[24] \&[25]$} \\
\hline Lack of awareness of e-commerce benefits & {$[12] ;[24] \&[31]$} \\
\hline Lack of qualified staff & {$[5] ;[17] ;[28] ;[32] \&[33]$} \\
\hline Lack of Internet security & [19]; [20]; [27]; [28]; 30]; [32]; [33] \& [34] \\
\hline Lack of external pressure from suppliers and customers & {$[29] \&[35]$} \\
\hline Lack of management support & [20]; [36] \& [37] \\
\hline Lack of technical know how & {$[23] ;[27] \&[36]$} \\
\hline Lack of financial resources & {$[12] ;[17] \&[20]$} \\
\hline Lack of popularity for online marketing and sales & {$[10] \&[22]$.} \\
\hline Lack of information on e-commerce & [20]; [22] \& [32] \\
\hline Lack of e-commerce standards & {$[23] \&[32]$} \\
\hline Lack of secure payment infrastructures & {$[23] \&[28]$} \\
\hline Low internet penetration & {$[17] \&[23]$} \\
\hline Low level of readiness among government institutions & {$[24] \&[25]$} \\
\hline Limited use of Internet banking and web portals by SMEs & {$[5] \&[38]$} \\
\hline Linguistic barriers & {$[20] ;[23] \&[25]$} \\
\hline No simple procedures and guidelines & {$[22] \&[39]$} \\
\hline Trade agreements & {$[22] \&[25]$} \\
\hline
\end{tabular}

\section{RESEARCH METHODOLOGY}

The main objective of this work is to investigate the barriers to e-commerce adoption in SMEs in Egypt. To fulfill the objective and achieve the goal, a framework for e-commerce adoption barriers in SMEs was used and a questionnaire was designed to collect the required information.
5.1 Framework for E-commerce Adoption Barriers in SMEs

E-commerce adoption is related to the level of ICT acquisition or adoption; therefore, investigation should be done with regarding to factors affecting ICT adoption in SMEs. The available researches reveal significant factors dealing with ICT and e-commerce adoption in SMEs, thirty barriers to e-commerce adoption were gathered from the literature. Several experts and professionals were interviewed to help in grouping the barriers. All interviewees agreed to group the thirty barriers into six groups as shown in the conceptual framework in figure (1). 


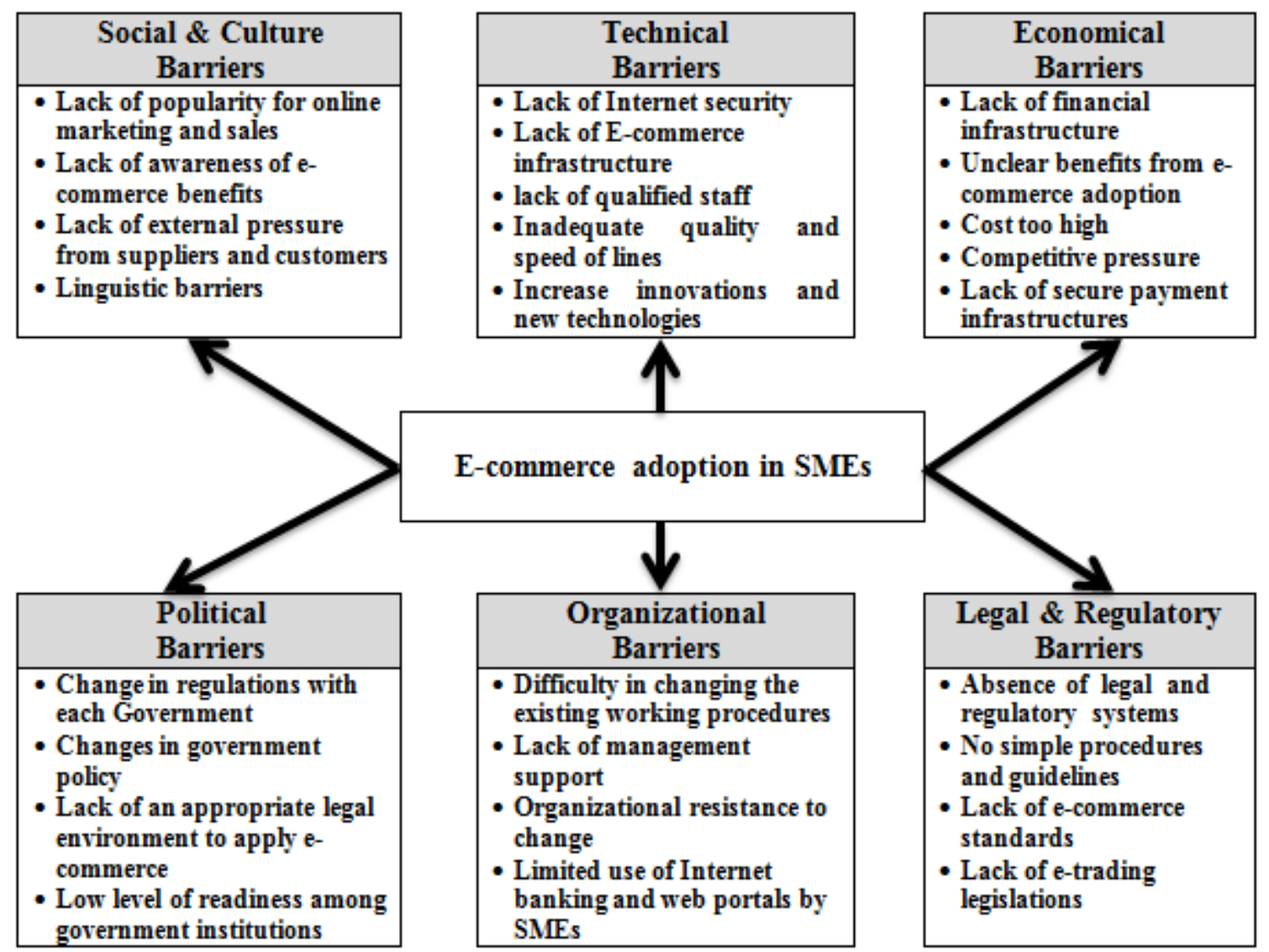

Figure 1. Conceptual framework for e-commerce adoption barriers in SMEs

\subsection{Questionnaire Design}

Structured questionnaire was used for data collection. The questionnaire was designed based on the conceptual framework for e-commerce adoption barriers in SMEs. The questionnaire consists of six groups with twenty six suggested barriers as shown in Appendix (I). in part "A", the participants were asked to rate their perception towards the most important barrier that affects e-commerce adoption within their enterprises on a five-point Likert-type scale with anchors from "5- Strongly agree" to "1- Strongly disagree"; whereas in part "B", they were asked to mention the highest e-commerce applications. The rating used to assess the degree of importance for each group of barriers or single barrier is ranked according table (2). The group of barriers or single barrier receives strong or medium rating is accepted as an effective barrier on e-commerce adoption in SMEs.

Table (2): Rating used to assess group of barriers or single barriers

\begin{tabular}{|c|l|c|}
\hline & Criteria & Rating \\
\hline 1 & $\begin{array}{l}\text { If the amount of population mean is greater than or equal 4.00, group of barriers or single barrier } \\
\text { has strong effect }\end{array}$ & +++ \\
\hline 2 & $\begin{array}{l}\text { If the amount of population mean is greater than or equal 3.00 and less than 4.00, group of } \\
\text { barriers or single barrier has medium effect }\end{array}$ & ++ \\
\hline 3 & $\begin{array}{l}\text { If the amount of population mean is less than 3.00, group of barriers or single barrier has low } \\
\text { effect }\end{array}$ & + \\
\hline
\end{tabular}

\subsection{Research Sample and Questionnaire Distribution}

The target population comprised small and medium enterprises (SMEs) in $10^{\text {th }}$ of Ramadan city; $6^{\text {th }}$ of October city; Sadat city and El-Obour city, Egypt. Stratified random sampling was used in selecting 150 enterprises working in the following fields:

- Wood and its Products

- Paper Products, Printing \& Publishing
- Engineering - Electronic \& Electrical Industries

- Lighting - Electricity \& Power Production

- Service \& Maintenance Centers

Two conditions were applied when selecting the sample: acceptance to participate and experience with e-service applications or at least has initiatives to apply e-commerce. After personal contact, ninety five enterprises were agreed to participate in the study conditioning to hide their names. Questionnaires were 
distributed via mail; Email and personally (two copies for each enterprise). To assure the participants quick and correct response; the questionnaire copies were sent directly to the owners and/or managers. The total numbers of received questionnaires were 147 copies out of 190 with total response rate $77.37 \%$ as shown in table (3).

Table (3): Response rate

\begin{tabular}{|l|c|c|c|c|}
\hline \multirow{2}{*}{ Sector } & No. of & \multicolumn{2}{c|}{ No. of questionnaires } & \multirow{2}{*}{ response rate } \\
\cline { 3 - 4 } & enterprises & distributed & received & \\
\hline Wood and its Products & 12 & 24 & 17 & $70.83 \%$ \\
\hline Paper Products, Printing \& Publishing & 13 & 26 & 19 & $73.08 \%$ \\
\hline Electronic \& Electrical Industries & 27 & 54 & 49 & $90.74 \%$ \\
\hline Electricity \& Power Production & 21 & 42 & 29 & $69.05 \%$ \\
\hline Service \& Maintenance Centers & 22 & 44 & 33 & $75.00 \%$ \\
\hline Total & 95 & 190 & 147 & $77.37 \%$ \\
\hline
\end{tabular}

\section{RESULTS AND DISCUSSIONS}

Some enterprises have websites (group of adopters $40 \%$ ) as shown in table (4), but most of them did not provide online sales processing; order tracking; online procurement and online payment. The top application being implemented by most of enterprises is electronic advertising (displaying enterprise information and products/services offered) as shown in table (5). The results show that there is no significant differences exist between enterprises that adapting and nonadapting ecommerce, so all respondents were combined to make a single sample. From the descriptive analysis's perspective, the average importance for the six groups of barriers ranged from 3.82 to 4.02 as indicated in table (6). Also, the results show that the twenty six barriers receive medium and strong rating (average importance between 3.1 and 4.63) as shown Appendix (II).

Table (4): Website usage

\begin{tabular}{|l|c|c|}
\hline \multirow{2}{*}{ Sector } & \multicolumn{2}{c|}{$\begin{array}{c}\text { Adopting } \\
\text { e-commerce }(\%)\end{array}$} \\
\cline { 2 - 3 } & Yes & No \\
\hline Wood and its Products & 25.00 & 75.00 \\
\hline $\begin{array}{l}\text { Paper Products, Printing \& } \\
\text { Publishing }\end{array}$ & 38.46 & 61.54 \\
\hline Electronic \& Electrical Industries & 33.33 & 66.67 \\
\hline Electricity \& Power Production & 33.33 & 66.67 \\
\hline Service \& Maintenance Centers & 63.64 & 36.36 \\
\hline \multicolumn{1}{|c|}{ Total } & 40.00 & 60.00 \\
\hline
\end{tabular}

Table (5): Usage of e-commerce applications

\begin{tabular}{|l|c|c|}
\hline \multirow{2}{*}{\multicolumn{1}{|c|}{ E-commerce Applications }} & \multicolumn{2}{|c|}{ Percentage (\%) } \\
\cline { 2 - 3 } & In use & $\begin{array}{c}\text { Not in } \\
\text { use }\end{array}$ \\
\hline Electronic Marketing & 60.53 & 39.47 \\
\hline Electronic Advertising & 76.32 & 23.68 \\
\hline Customer Support Service & 42.11 & 57.89 \\
\hline Order and Delivery & 26.32 & 73.68 \\
\hline Payment System & 0.00 & 100.00 \\
\hline
\end{tabular}

Table (6): Average importance for the six groups of barriers

\begin{tabular}{|l|c|c|}
\hline \multicolumn{1}{|c|}{ Groups of barriers } & Mean & Rating \\
\hline Social \& Culture Barriers & 3.79 & ++ \\
\hline Technical Barriers & 4.02 & +++ \\
\hline Economical Barriers & 3.82 & ++ \\
\hline Political Barriers & 3.98 & ++ \\
\hline Organizational Barriers & 3.83 & ++ \\
\hline Legal \& Regulatory Barriers & 4.00 & $\mathbf{+ + +}$ \\
\hline
\end{tabular}

According to the results, technical barriers are the most important barriers followed by legal and regulatory barriers then political barriers, and the least important barriers are social and culture barriers. All respondents agreed that lack of Internet security (4.63) is the highest barrier that inhibit the implementation of e-commerce in SMEs in Egypt, whereas the majority (over 80\%) of respondents ranked the following barriers: limited use of Internet banking and web portals by SMEs (4.33); cost too high (4.22); changes in government policy and lack of e-commerce standards (4.20) as the most important barriers as shown in table (7). Barriers like difficulty in changing the existing working procedures (3.1); and lack of external pressure from suppliers and customers (3.29) received low importance compared with other barriers as shown in table (8). 
Table (7): Average importance for the highest barriers in the six groups

\begin{tabular}{|c|c|c|c|c|c|c|c|}
\hline \multirow{2}{*}{ Barriers } & \multicolumn{5}{|c|}{ No. of participants } & \multirow{2}{*}{ Mean } & \multirow{2}{*}{ Rating } \\
\hline & 1 & 2 & 3 & 4 & 5 & & \\
\hline Lack of Internet security & 0 & 0 & 0 & 55 & 92 & 4.63 & +++ \\
\hline Limited use of Internet banking and web portals by SMEs & 5 & 7 & 12 & 34 & 89 & 4.33 & +++ \\
\hline Cost too high & 6 & 5 & 16 & 44 & 76 & 4.22 & +++ \\
\hline Organizational resistance to change & 6 & 12 & 5 & 47 & 77 & 4.20 & +++ \\
\hline Changes in government policy & 5 & 9 & 11 & 55 & 67 & 4.16 & +++ \\
\hline Lack of e-commerce standards & 9 & 10 & 7 & 50 & 71 & 4.12 & +++ \\
\hline Lack of awareness of e-commerce benefits & 9 & 12 & 9 & 44 & 73 & 4.09 & +++ \\
\hline Absence of legal and regulatory systems & 8 & 11 & 9 & 51 & 68 & 4.09 & +++ \\
\hline lack of qualified staff & 7 & 10 & 14 & 51 & 65 & 4.07 & +++ \\
\hline Change in regulations with each Government & 11 & 13 & 6 & 47 & 70 & 4.03 & +++ \\
\hline
\end{tabular}

Table (8): Average importance for the lowest barriers in the six groups

\begin{tabular}{|c|c|c|c|c|c|c|c|}
\hline \multirow{2}{*}{ Barriers } & \multicolumn{5}{|c|}{ No. of participants } & \multirow{2}{*}{ Mean } & \multirow{2}{*}{ Rating } \\
\hline & 1 & 2 & 3 & 4 & 5 & & \\
\hline Difficulty in changing the existing working procedures & 44 & 15 & 11 & 37 & 40 & 3.10 & ++ \\
\hline Lack of external pressure from suppliers and customers & 17 & 23 & 32 & 51 & 24 & 3.29 & ++ \\
\hline Unclear benefits from e-commerce adoption & 31 & 16 & 15 & 31 & 54 & 3.41 & ++ \\
\hline Lack of management support & 22 & 15 & 8 & 42 & 60 & 3.70 & ++ \\
\hline Low level of readiness among government institutions & 12 & 16 & 21 & 32 & 66 & 3.84 & ++ \\
\hline Linguistic barriers & 10 & 11 & 23 & 45 & 58 & 3.88 & ++ \\
\hline Lack of e-trading legislations & 19 & 10 & 9 & 40 & 69 & 3.88 & ++ \\
\hline Lack of an appropriate legal environment to apply e-commerce & 10 & 13 & 19 & 47 & 58 & 3.88 & ++ \\
\hline
\end{tabular}

These findings matched the results in similar studies conducted by Kartiwi \& MacGregor ${ }^{[32]}$ in Indonesia; Kshetri ${ }^{[17]}$ in Nepal; Kapurubandara \& Lawson ${ }^{[22]}$ in Sri Lanka; Fathian et al. ${ }^{[30]}$ in Iran; Alshehri \& Drew ${ }^{[20]}$ in Saudi Arabia; Alamro \& Tarawneh, ${ }^{[21]}$ in Jordan and Olatokun \& Bankole ${ }^{[28]}$ in Nigeria. Referring to the study done by El-Nawawy and Ismail ${ }^{[13]}$, after more than ten years, most of ecommerce barriers mentioned in this study were solved except cost and legal issues still need some improvements.

\section{CONCLUSIONS}

E-commerce has the potential to greatly improve how enterprise operates internally and how it serves its customers. E-commerce is much more than a tool for improving cost-quality ratios in SMEs services. This preliminary research investigated the factors that influence and inhibit the implementation of ecommerce in SMEs in Egypt. Based on the literature and the results of this research, the following conclusions are drawn.

- $\quad$ First of all, the results showed that most of SMEs in Egypt have only adopted basic applications. They widely adopted the most common ecommerce technologies (e-mail and Internet) as additional marketing tools to display company's products and services information, rather than as an e-commerce platform to enable online transactions. Indeed, the adoption of e-commerce applications like online payment system, order processing is at a relatively low level. The findings implied that more efforts are needed to help and encourage SMEs in Egypt to speed up e-commerce adoption, particularly the more advanced applications.

- Secondly, factors that may hinder the implementation of e-commerce are: lack of Internet security and limited use of Internet banking and web portals by SMEs. So, security and privacy are critical issues that need to take the highest level of priority in e-commerce implementation process.

- Thirdly, with regard to the planning and implementation of e-commerce, creating a uniform strategic plan for e-commerce projects is the first step for successful adoption of e-commerce. Also, issues relating to Egyptian culture and societal structure should be addressed very carefully to influence and convince the Egyptian citizens to participate and become involved in e-commerce systems.

- Fourthly, citizen's awareness of e-commerce and other new e-services need be addressed to raise and promote the e-commerce benefits and advantages.

\section{RESEARCH RECOMMENDATIONS}

Based on the research result, the following suggested recommendations could help successful adoption of ecommerce in Egyptian SMEs:

1. Develop a political vision; strategic objectives; policies and design mechanisms for the cooperation between parties to control e-services, regardless type of service. 
2. Adopt programs to protect the information to prevent misuse and to increase Internet security.

3. Attention and media publicity to increase public awareness to push customers and employees to make use of e-commerce.

4. Determine the strategic priorities of e-commerce adoption and redesign some of the actions in order to cope with the provision of e-commerce.

5. Study and simulation of the best experiences of egovernment worldwide.

6. Continued focus on improving technical infrastructure necessary for the operation of ecommerce and the procedures and internal systems support e-commerce.

7. Finally, Government should improve the legal infrastructure such as privacy law, e-signature and knowledge acquisition law.

\section{LIMITATION OF THE STUDY}

It should be noted that this study has several limitations. The data for the study were collected from various industry sectors, and it is not possible to make sector specific conclusions. Also, this is a quantitative study and further qualitative research is required to gain a better understanding of the key issues of ecommerce adoption in SMEs.

\section{REFERENCES}

[1] Simpson M. \& Docherty A., "E-commerce adoption support and advice from UK SMEs" Journal of small business and enterprise development, 2004, 11(3): 315 - 328.

[2] Fillis I., Johansson U. \& Wagner B., "A conceptualization of the opportunities and barriers to e-business development in the smaller firm", Journal of Small Businesses and Enterprise Development, 2003, 10(3): 336-344.

[3] Bolongkikit J., Obit J., Asing J., \& Tanakinjal G., "An exploratory research of the usage level of ecommerce among SMEs in the West Coast Sabah, Malaysia", 2006. Available on line at: http://www.arraydev.com/commerce/JIBC/200608/Bolongkikit.asp.

[4] Taylor M. \& Murphy A., "SMEs and e-business", Journal of small business and enterprise development, 2004, 11(3): 280 - 289.

[5] Kapurubandara M., 'A framework to e-transform SMEs in Developing Countries', Electronic Journal of Information Systems in Developing Countries, 2009, 39(3): 1-24.

[6] EIU, Economist Intelligence Unit, 2009, Available at: http://www2.accaglobal.com/ documents/surviving_drought.pdf.

[7] MOFT (Ministry of Foreign Trade), "MSME Definition Study (PHASE II) - Final Report", Ministry of Foreign Trade, 2004. Available at:
http://www.sme.gov.eg/English_publications/Defin ition.pdf

[8] Fraser J., Fraser N. \& McDonald F., 'The strategic challenge of electronic commerce", Supply Chain Management: An International Journal, 2000, 5(1): 7-14.

[9] Eurostat, "E-commerce and the Internet in European Businesses", European Communities, Luxembourg, 2004.

[10] Terzi N., "The impact of e-commerce on international trade and Employment", Procedia Social and Behavioral Sciences, 2011, 24: 745-753.

[11]Huff S. \& Yoong P., "SMEs and E-commerce: Current Issues and Concerns: A Preliminary Report", International Conference on E-commerce, Kuala Lumpur, Malaysia, 2000.

[12] Stockdale R. \& Standing C., "A classification model to support SME e-commerce adoption initiatives", Journal of Small Business and Enterprise Development, 2006, 13(3): 381-394.

[13]El-Nawawy M. \& Ismail M., "Overcoming deterrents and impediments to electronic commerce in light of Globalization", Proceedings of the $9^{\text {th }}$ annual conference of the internet society, INET 99, San Jose, USA, 22 - 25 June 1999.

[14] Cloete E., Courtney S. \& Fintz J., "Small businesses" acceptance and adoption of ecommerce in the western-cape province of SouthAfrica", Electronic Journal on Information Systems in Developing Countries, 2002, 10(4): 1-13. Available at: http://www.ejisdc.org.

[15] Chen S., "Adoption of Electronic Commerce by SMEs of Taiwan", Electronic Commerce Studies, 2004, 2(1); 19-34.

[16] Kaynak E., Tatoglu E. \& Kula V., “An analysis of the factors affecting the adoption of electronic commerce by SMEs: evidence from an emerging market", International marketing Review, 2005, 22(6): $632-640$.

[17] Kshetri N., "Barriers to e-commerce and competitive business models in developing countries: A case study", Electronic Commerce Research and Applications, 2007, 6: 443-452.

[18]Rakhmanov E., "The Barriers Affecting Egovernment Development in Uzbekistan", $4^{\text {th }}$ International Conference on Computer Sciences and Convergence Information Technology, 2009. ICCIT '09, 24-26 Nov. Seoul, South Korea: 1474 1480.

[19] Olatokun W. \& Kebonye M., "e-Commerce Technology Adoption by SMEs in Botswana", International Journal of Emerging Technologies and Society, 2010, 8(1): $42-56$.

[20] Alshehri M. \& Drew S., "Challenges of eGovernment Services Adoption in Saudi Arabia from an e-Ready Citizen Perspective", World Academy of Science, Engineering and Technology, 2010, 66: 1053-1059.

[21] Alamro S. \& Tarawneh S., "Factors Affecting ECommerce Adoption in Jordanian SMEs", 
European Journal of Scientific Research, 2011, 64(4): 497-506.

[22] Kapurubandara M. \& Lawson R. "Mergence: Merging and Emerging Technologies, Processes, and Institutions", $20^{\text {th }}$ Bled e-Conference $e$ commerce, June 4 - 6, 2007; Bled, Slovenia.

[23] Lawrence J. \& Tar U., "Barriers to ecommerce in developing countries", Information, Society and Justice, 2010, 3(1): 23-35.

[24]Zaied A., Al-Khairalla F. \& Al-Rashed W., "Assessing e-Readiness in the Arab Countries: Perceptions towards ICT Environment in Public Organizations in the State of Kuwait", Electronic Journal of e-Government, 2007, 5(1): 77 - 86.

[25] Al jehail A., "Success factors towards applying eservices in ministry of defense in the State of Kuwait", M.Sc. thesis in technology Management, Arabian Gulf University, Bahrain, 2008.

[26] MacGregor, R. and Vrazalic, L. (2005) "A basic model of electronic commerce adoption barriers: a study of regional businesses in Sweden and Australia" Journal of small business and enterprise development, 12(4): 510 -527.

[27] Hourali M., Fathian M., Montazeri A. \& Hourali A., "A Model for E-Readiness Assessment of Iranian Small and Medium Enterprises", Journal of Faculty of Engineering, 2008, 41(7): 969-985.

[28] Olatokun W. \& Bankole B. "Factors Influencing Electronic Business Technologies Adoption and Use by Small and Medium Scale Enterprises (SMES) in a Nigerian Municipality", Journal of Internet Banking and Commerce, 2011, 16(3): 1-26

[29] Chitura T., Mupemhi S., Dube T. \& Bolongkikit J. "Barriers to Electronic Commerce Adoption in Small and Medium Enterprises: A Critical Literature Review", Journal of Internet Banking and Commerce, 2008, 13(2); 1-13. Available at: http://www.arraydev.com/commerce/jibc.

[30] Fathian M., Akhavan P. \& Hoorali M., "Ereadiness assessment of non-profit ICT SMEs in a developing country: The case of Iran", Technovation, 2008, 28: 578 - 590 .

[31] Thulani D., Tofara C. \& Langton R., "Electronic Commerce Benefits and Adoption Barriers in Small and Medium Enterprises in Gweru, Zimbabwe", Journal of Internet Banking and Commerce, 2010, 15(1): 1-17.

[32] Kartiwi M. \& MacGregor R., "Electronic commerce adoption barriers in small to mediumsized Enterprises (sMEs) in Developed and Developing countries: A cross- country comparison", Journal of Electronic Commerce in Organizations, 2007, 5(3): 35-51.
[33] Quader S. \& Abdullah M., "Constraints to SMEs: A Rotated Factor Analysis Approach”, A Research Journal of South Asian Studies, 2009, 24(2): $334-350$

[34] Lawson R., Alcock C., Cooper J. \& Burges L., "Factors affecting adoption of electronic technologies by SMEs: an Australian study", Journal of small Business and enterprise development, 2003, 10(3): 265 - 276.

[35]Looi H., "A model of factors influencing electronic commerce adoption among small and medium enterprises in Brunei Darussalam", International Journal of information technology, 2003, 10(1): 72- 87.

[36] Ramsey E., Ibbotson P., Bell J. \& Gray D., "E opportunities of service Sector SMEs: an Irish cross- border study", Journal of small business and enterprise development, 2003, 10(3): 250 - 264.

[37] Sarkar A., "E-Commerce Adoption and Implementation in SMEs: An Analysis of Factors", $21^{\text {st }}$ Annual Conference of the National Advisory Committee on Computing Qualifications (NACCQ), Auckland, New Zealand, 2008: 309-319.

[38] Lane M., Vyver G., Delpachitra S. \& Howard S., "An electronic commerce initiative in regional Sri Lanka: the vision for the central province, Electronic commerce Portal", Electronic Journal on information systems in Developing countries, 2004, 16(1): 1 - 18

[39] MacGregor R., "Perception of Barriers to eCommerce adoption in SMEs in a Developed and Developing Country: a Comparison between Australia and Indonesia", Journal of Electronic Commerce in Organizations, 2010, 8(1): 61-82.

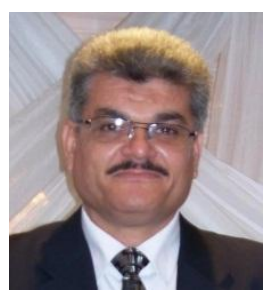

Abdel Nasser H. Zaied is a Vicedean for education and students affairs, College of Computers and Informatics, Zagazig University, Egypt. He previously worked as an associate professor of Industrial Engineering, Zagazig University Egypt;an assistant professor of Technology Management, Arabian Gulf University, Bahrain; and as visiting professor at Oakland University, USA. He supervised $9 \mathrm{PhD}$. thesis and 39 MSc. thesis, and examined 33 MSc thesis. He published sixteen research papers in International and Regional Journals and 22 research papers in International and National conferences. His areas of research are: Systems Analysis and Design; Information Security; Knowledge Management; Quality Management Systems and project Management, Electronic applications. 
Appendix (I): Questionnaire

Part A: E-commerce Adoption Barriers

Adopting e-commerce?

Yes

No

$1=$ Strongly Disagree, $2=$ Disagree, $3=$ Neutral, $4=$ Agree, and $5=$ Strongly Agree

Our enterprise does not use e-commerce because of:

\begin{tabular}{|c|c|c|c|c|c|c|}
\hline \multicolumn{2}{|c|}{ Social \& Culture Barriers } & 1 & 2 & 3 & 4 & 5 \\
\hline \multirow{4}{*}{1} & Lack of popularity for online marketing and sales & & & & & \\
\hline & Lack of awareness of e-commerce benefits & & & & & \\
\hline & Lack of external pressure from suppliers and customers & & & & & \\
\hline & Linguistic barriers & & & & & \\
\hline \multicolumn{2}{|c|}{ Technical Barriers } & 1 & 2 & 3 & 4 & 5 \\
\hline \multirow{5}{*}{2} & Lack of Internet security & & & & & \\
\hline & E-commerce infrastructure & & & & & \\
\hline & lack of qualified staff & & & & & \\
\hline & Inadequate quality and speed of lines & & & & & \\
\hline & Increase innovations and new technologies & & & & & \\
\hline \multicolumn{2}{|c|}{ Economical Barriers } & 1 & 2 & 3 & 4 & 5 \\
\hline \multirow{5}{*}{3} & Lack of financial infrastructure & & & & & \\
\hline & Unclear benefits from e-commerce adoption & & & & & \\
\hline & Cost too high & & & & & \\
\hline & Competitive pressure & & & & & \\
\hline & Lack of secure payment infrastructures & & & & & \\
\hline \multicolumn{2}{|c|}{ Political Barriers } & 1 & 2 & 3 & 4 & 5 \\
\hline \multirow{4}{*}{4} & Change in regulations with each Government & & & & & \\
\hline & Changes in government policy & & & & & \\
\hline & Lack of an appropriate legal environment to apply e-commerce & & & & & \\
\hline & Low level of readiness among government institutions & & & & & \\
\hline \multicolumn{2}{|c|}{ Organizational Barriers } & 1 & 2 & 3 & 4 & 5 \\
\hline \multirow{4}{*}{5} & Difficulty in changing the existing working procedures & & & & & \\
\hline & Lack of management support & & & & & \\
\hline & Organizational resistance to change & & & & & \\
\hline & Limited use of Internet banking and web portals by SMEs & & & & & \\
\hline \multicolumn{2}{|c|}{ Legal \& Regulatory Barriers } & 1 & 2 & 3 & 4 & 5 \\
\hline \multirow{4}{*}{6} & Absence of legal and regulatory systems & & & & & \\
\hline & No simple procedures and guidelines & & & & & \\
\hline & Lack of e-commerce standards & & & & & \\
\hline & Lack of e-trading legislations & & & & & \\
\hline
\end{tabular}

Part B: E-commerce Applications

\begin{tabular}{|l|l|l|}
\hline E-commerce Applications & In use & Not in use \\
\hline Electronic Marketing & & \\
\hline Electronic Advertising & & \\
\hline Customer Support Service & & \\
\hline Order and Delivery & & \\
\hline Payment System & & \\
\hline
\end{tabular}

Appendix (II): Summary of Results

\begin{tabular}{|c|c|c|c|c|c|c|c|c|}
\hline \multirow{2}{*}{\multicolumn{2}{|c|}{ Barriers }} & \multicolumn{5}{|c|}{ No. of participants } & \multirow{2}{*}{ Mean } & \multirow{2}{*}{ Rating } \\
\hline & & 1 & 2 & 3 & 4 & 5 & & \\
\hline \multicolumn{2}{|c|}{ Social \& Culture Barriers } & \multicolumn{6}{|c|}{3.79} & ++ \\
\hline \multirow{4}{*}{1} & Lack of popularity for online marketing and sales & 5 & 7 & 33 & 45 & 57 & 3.97 & ++ \\
\hline & Lack of awareness of e-commerce benefits & 9 & 12 & 9 & 44 & 73 & 4.09 & +++ \\
\hline & Lack of external pressure from suppliers and customers & 17 & 23 & 32 & 51 & 24 & 3.29 & ++ \\
\hline & Linguistic barriers & 10 & 11 & 23 & 45 & 58 & 3.88 & ++ \\
\hline \multicolumn{2}{|c|}{ Technical Barriers } & \multicolumn{6}{|c|}{4.02} & ++ \\
\hline \multirow{5}{*}{2} & Lack of Internet security & 0 & 0 & 0 & 55 & 92 & 4.63 & +++ \\
\hline & Lack of E-commerce infrastructure & 12 & 16 & 21 & 32 & 66 & 3.84 & ++ \\
\hline & lack of qualified staff & 7 & 10 & 14 & 51 & 65 & 4.07 & +++ \\
\hline & Inadequate quality and speed of lines & 9 & 10 & 22 & 49 & 57 & 3.92 & ++ \\
\hline & Increase innovations and new technologies & 25 & 21 & 6 & 31 & 64 & 3.96 & ++ \\
\hline
\end{tabular}




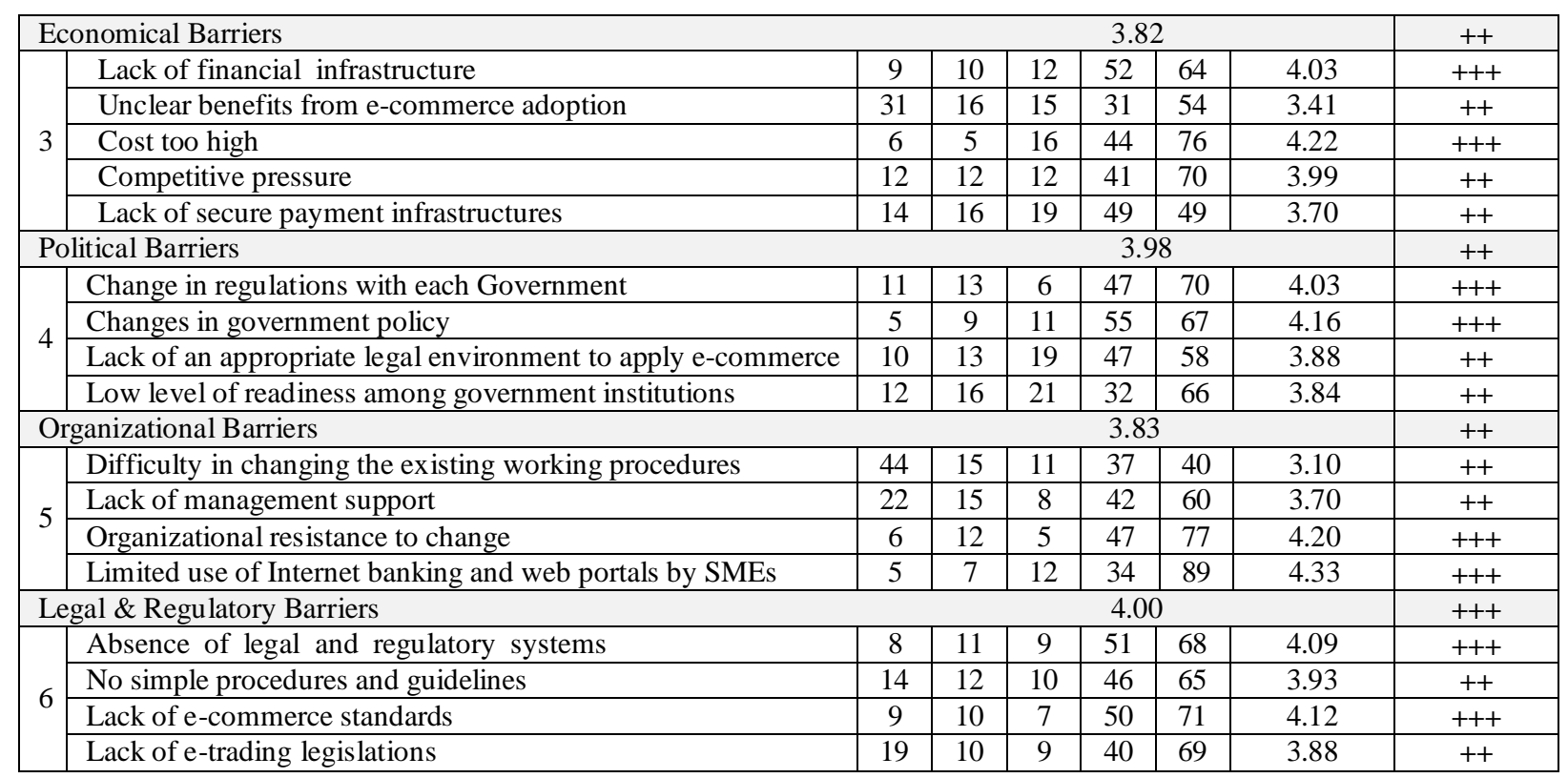

